Institute of $\mathbf{F}_{\text {ood and }} \mathbf{A}_{\text {gricultural }} \mathbf{S}_{\text {ciences }}$

\title{
2003 Handbook of Employment Regulations Affecting Florida Farm Employers and Workers: Transportation -- Motor Carrier Safety Regulations for Drivers of Farm Trucks [Federal] ${ }^{1}$
}

Leo C. Polopolus, Michael T. Olexa, Fritz Roka, and Carol Fountain ${ }^{2}$

\section{Purpose}

Establishes safety and licensing standards for trucks, buses, and semi-trailers where gross vehicle weight exceeds 10,000 pounds.

\section{Program Requirements}

The U.S. Department of Transportation's (DOT) Motor Carrier Safety Regulations cover all interstate and intrastate motor carriers of property or passengers whether common, contract, or private, including drivers, officers, agents, representatives, and employees.
The two broad areas of the safety regulations relevant to agriculture include:

- Drivers of farm trucks subject to Commercial Driver's License (CDL) requirements and hazardous materials regulations.

- Vehicles and drivers transporting migrant farmworkers. (See EDIS document FE406, Migrant and Seasonal Agricultural Worker Protection Act (MSPA) [Federal].)

1. This is EDIS document FE417, a publication of the Department of Food and Resource Economics, Florida Cooperative Extension Service, Institute of Food and Agricultural Sciences, University of Florida, Gainesville, FL. Published July 2003. This information is included in Circular 1200, Handbook of Employment Regulations Affecting Florida Farm Employers and Workers. First published February 1992 as Circular 1043. Revised December 2002 as Circular 1200. Please visit the EDIS website at http://edis.ifas.ufl.edu.

2. Leo C. Polopolus, Professor Emeritus, Department of Food and Resource Economics, University of Florida, Gainesville, FL; Michael T. Olexa, Professor, Department of Food and Resource Economics, University of Florida, Gainesville, FL; Fritz Roka, Associate Professor, Department of Food and Resource Economics, Southwest Florida Research and Education Center, Immokalee, FL; and Carol Fountain, Assistant Editor, Department of Food and Resource Economics, University of Florida, Gainesville, FL; Florida Cooperative Extension Service, Institute of Food and Agricultural Sciences, University of Florida, Gainesville, FL.

This document is designed to provide accurate, current, and authoritative information on the subject. However, since the laws, administrative rulings, and court decisions on which it is based are subject to constant revision, portions of this publication could become outdated at any time. This publication is distributed with the understanding that the authors are not engaged in rendering legal or other professional advice, and the information contained herein should not be regarded as a substitute for professional advice. For these reasons, the utilization of these materials by any person constitutes an agreement to hold harmless the authors, the Institute of Food and Agricultural Sciences, and the University of Florida for any liability claims, damages, or expenses that may be incurred by any person as a result of reference to or reliance on the information contained in this publication.

The Institute of Food and Agricultural Sciences is an equal opportunity/affirmative action employer authorized to provide research, educational information and other services only to individuals and institutions that function without regard to race, color, sex, age, handicap, or national origin. For information on obtaining other extension publications, contact your county Cooperative Extension Service office. Florida Cooperative Extension Service/Institute of Food and Agricultural Sciences/University of Florida/Christine Taylor Waddill, Dean. 


\section{Farm Vehicle Waivers}

The Motor Carrier Safety Regulations permit states to waive the CDL requirements for certain groups. These include certain farm vehicle operators as long as the vehicle:

- Is controlled and operated by a farmer.

- Is used to transport agricultural products or farm machinery/farm supplies or both to and from a farm.

- Is not used in the operation of a common or contract motor carrier.

- Is used within 150 miles of the person's farm.

This is not a blanket waiver for all drivers of all farm-related vehicles. At its broadest interpretation, it applies only to the farmer-operator of vehicles hauling nonhazardous materials that do not travel more than 150 miles from the farm.

In addition, CDL waivers do not apply to drivers of vehicles designed to transport passengers, including migrant or seasonal agricultural workers.

For these reasons, it is important for farm employers to understand and comply with DOT regulations governing road testing, medical examinations, drug and alcohol testing, equipment, maintenance, and transportation of hazardous materials.

\section{Physical Requirements of Drivers}

Drivers of farm vehicles must meet the physical requirements and comply with all other provisions of the Federal Motor Carrier Safety Regulations:

- A person cannot drive a farm vehicle if he or she has lost a foot, leg, hand, or arm unless he or she has been granted a waiver.

- A person cannot have any impairment of a hand or finger which interferes with prehension or power grasping, or an arm, foot, or leg which interferes with the ability to perform normal tasks associated with operating a motor vehicle.
- A driver of a farm vehicle cannot have diabetes, cardiovascular disease, respiratory dysfunction, high blood pressure, arthritis, rheumatism, or epilepsy likely to interfere with the ability to control or drive a motor vehicle safely.

- The driver of a farm vehicle must have visual acuity of at least 20/40 with corrective lenses and not be color blind, must have hearing which is not significantly diminished, and must not be addicted to habit-forming drugs or alcohol.

\section{Other Requirements}

\section{Driver's Qualification File}

- Each driver must have a qualification file which may be kept with the driver's personnel file. Operators are required to keep the files at their principal place of business and retain them for three years after termination of the employee.

- If you meet the definition of a farm vehicle operator, you are exempt from the driver's qualification file portion of the regulation.

\section{Road Tests}

- Each person must be tested to demonstrate that he or she is capable of operating the type of motor vehicle he or she intends to drive.

- A driver may present a valid operator's license issued by the state driver's license testing bureau as an alternative to the road test. If he or she does, the employer must photocopy the license and keep it with the driver's qualification file. If the employer chooses to use the road test, it must be given by a person who is competent to evaluate whether the individual taking the test has demonstrated he or she is capable of operating the equipment.

- If you meet the definition of a farm vehicle operator, you are exempt from this section of the regulation.

\section{Medical Examination}

- The medical examination must be given by a licensed doctor every two years and must be included in the driver's qualification file. The 
driver of a motor vehicle must have in his or her possession a medical examiner certificate card or a photocopy of the medical examination.

- All farm vehicle operators are exempt from the requirements for medical examinations. If you drive a combination vehicle, such as a tractor-trailer, you need to have a medical examination but you do not need to keep a copy of the examination on you.

\section{Driving Requirements}

- Employers cannot permit motor vehicles to be operated when the driver's ability or alertness is impaired due to fatigue, illness, or any other reason.

- Drivers may not possess or use any prohibited drugs, amphetamines, or other substances that could jeopardize the safe operation of a motor vehicle.

- Drivers may not use, possess, or have any measurable amount of detectable alcohol while driving or while on duty. They are also prohibited from consuming alcoholic beverages within four hours of going on duty.

- Drivers violating these rules must be placed out of service for twenty-four hours.

\section{Equipment}

- The following emergency equipment must be carried on all vehicles in the proper place and ready for use:

- One fire extinguisher (Type 5BC or larger: properly filled, accessible, and securely mounted).

- Tree emergency bi-directional reflective triangles, fuses, or flares.

- One spare fuse or other overload protective device for each type and size used.

- This part of the regulation (Part 393) also details the requirements for lighting devices, reflectors, electrical equipment, brakes, glazing/window construction, fuel systems, coupling devices and towing methods, emergency equipment, protection against shifting or falling cargo, tires, mirrors, horn, rear end projection, loads, and seat belts.

\section{Inspection and Maintenance}

- Motor carriers must systematically inspect, repair, and maintain all their vehicles.

- Every driver must complete a written vehicle inspection report at the end of each workday on each vehicle operated. Before dispatching the vehicle, the owner must certify on the report that defects, if any, have been corrected or are unnecessary. The report must be kept for ninety days.

- Owners operating only one motor vehicle are exempt from this requirement.

- Vehicles not passing inspection by enforcement officers and because their condition might cause an accident or breakdown must be taken out of service until repairs are made.

\section{Hourse of Service Limitations}

The hours of service rules prohibit drivers from:

- Driving more than ten hours following eight consecutive hours off-duty.

- Driving for any period after being on duty fifteen hours following eight hours off-duty.

- Driving after having been on-duty more than sixty hours in any seven consecutive days.

- Driving after having been on-duty more than seventy hours in any period of eight consecutive days (for carriers that operate seven days a week).

These rules have been a source of contention for agricultural retailers and other farm suppliers who were able to win a partial exemption in late 1995.

The law now exempts drivers transporting agricultural commodities or farm supplies for agricultural purposes within a state from the rules under these conditions: 
- Transportation is limited to a 100 -mile radius from the source of the commodities or the distribution point.

- Transportation occurs during the state's planting and harvest seasons as determined by each state.

\section{Penalties}

Violations of the federal Motor Carrier Safety Regulation carry fines ranging from $\$ 1,000$ for the first offense up to $\$ 10,000$ for willful repeat offenses.

\section{Related Information}

- Federal Motor Carrier Safety Regulations, C.F.R., Title 49, Chapter III, Subchapter B, Part 398, U.S. Department of Transportation, Federal Highway Administration, Bureau of Motor Carrier Safety.

- Commercial Driver's License: Manual for Truck and Bus Drivers, Florida Department of Highway Safety and Motor Vehicles.

\section{Responsible Agency}

U.S. Department of Transportation

Federal Highway Administration

Office of Motor Carrier Safety

61 Forsyth Street SW, Suite 17T75

Atlanta, GA 30367

(404) $562-3600$

http://www.fmcsa.dot.gov/aboutus/aboutus.htm 